\title{
Study on Psychological Health Problems and Countermeasures of University Student
}

\author{
Yunfeng Li \\ School of Mechatronic Engineering, Southwest Petroleum University, Chengdu, China \\ Email: liyunfeng2014@hotmail.com
}

How to cite this paper: Li, Y. F. (2017). Study on Psychological Health Problems and Countermeasures of University Student. Creative Education, 8, 1795-1802. https://doi.org/10.4236/ce.2017.812123

Received: September 1, 2017

Accepted: September 17, 2017

Published: September 20, 2017

Copyright $\odot 2017$ by author and Scientific Research Publishing Inc. This work is licensed under the Creative Commons Attribution International License (CC BY 4.0).

http://creativecommons.org/licenses/by/4.0/

\begin{abstract}
Nowadays, university graduates are major contributors of social development, therefore their psychological health draws attention of the whole society. Facing the mental health problems of college students, the reasons of effective countermeasures were researched, and some suggestions for solving the college mental health problems were provided. This paper argues that the current mental health problems are complex and diverse, mainly from the social environment, the negative energy oriented education, family education and school students self concept development imbalance caused by four aspects. According to the psychological health problems of college students, this paper puts forward that to vigorously promote the social environment of positive energy, schools should strive to practice quality education, students should pay attention to family education and the students themselves should pay more attention to the balanced development.
\end{abstract}

\section{Keywords}

College Students, Psychological Health, Psychological Health Education, Causes and Countermeasures

\section{Introduction}

College students, because of that their psychological and physical maturity is not mature, lack of self-psychological management ability, under the influence of colleges and universities, society and family, so that they have a lot of mental health problems in life, study and socialization (Wegge, Schmidt, Parkes, \& van Dick, 2007). These psychological problems caused the accumulation of negative emotions, and if in this situation for a long time, it will affect their quality of life and personality development (Saari \& Judge, 2004). This also confirms the fact that the mental quality of college students has declined year by year in recent 
years (Mount, Ilies, \& Johnson, 2006). With the college students' mental health, education has also been a great development, but the mental health of college students is still not optimistic. In the first place, the existence of university organizations is not enough to pay attention to the lifetime benefit of mental health education, the management is relatively loose; the shortage of teachers, the shortage of funds and the low efficiency; lack of understanding of the law of college students' development, lack of corresponding mental health education and other phenomena (Rode, 2004). Second, Sichuan Province is an economically underdeveloped city, the information is relatively closed, and the development of human resources has been seriously affected. Society has the bad values, the employment situation is grim, the introduction of the talented people's minds and policies are relatively backward, the cultural development of Sichuan Province is relatively backward, the quality of the public have a certain gap with developed cities; foreign population increased year by year, college students are affected by the impact of multiculturalism (Judge, Locke, \& Durham, 1997). Thirdly, the parents of college students in Sichuan Province are generally in lower education level, their own educational philosophy are backward and lack of concern for their children's mental health development (Walster, Berscheid, \& Walster, 1973). Although some parents gradually realized the importance of mental health education, they are still dependent on college education. These phenomena have different effects on the development of college students' mental health (Huseman, Hatfield, \& Miles, 1987). In summary, the author makes the author's research on the mental health status and the main mental health problems of college students in Sichuan province, and how to prevent and solve these problems (Whisman \& Uebelacker, 2003). On the current development needs of college students, as well as the future development of China's economic and cultural trends, the study of college students mental health problems have a profound significance (Bauserman, Arias, \& Craighead, 1995).

\section{The Main Problems in the Psychological Health Education}

At present, the realities faced by college students are more complicated than those faced by college students a few years ago (Vega, Bayon, Franco, Canas, Graell, \& Salvador, 1993). The stress and challenge from academic, employment, economic and emotional aspects have caused worrisome problems in their mental health. Since the 1980s, domestic scholars began to use a variety of methods to study the mental health of college students, in the higher education environment, the students should have a positive mental health status (Arrindell \& Emmelkamp, 1986), but the results show that college students are far below other groups of the same age group. In today's social education and school education, teachers, parents or employers, are too much emphasis on student achievement is good or bad, but often overlooked the importance of their perfect personality (Chambless, Fauerbach, Floyd, Wilson, Remen, \& Renneberg, 2002). In this way, it will accelerate the emergence of mental health problems of college 
students, such as selfishness, indifference, loneliness, extreme, empty, bored, greedy to enjoy, self-centered and so on. However, in many cases the mental health problems have not received enough attention. Thus, every time a tragedy occurs, the teacher, the parent, and the society show a surprise and inconceivable. Do you not know that these problems are formed over time. In the face of the emergence of mental health problems of college students, we should give a high degree of attention.

1) The reality of social environment caused negative mental health problems

With the general development of China's social economy, the social competition pressure in Sichuan Province is getting bigger and bigger; the pace of life is getting faster and faster (Fals-Stewart, Birchler, \& O'Farrell, 1999). Coupled with the fusion of Chinese and western culture, college students are influenced by politics, economy and culture. The Such as the development of college students in the process of gradually forming the world outlook and values, at any time may be due to the impact of a social phenomenon changes. For example, due to the rapid development of the network, making a variety of values continue to influx of people's minds. A variety of social and cultural forms continue to show through the new media in front of college students, some foreign hostile forces and even the use of new media for cultural infiltration, spread of violent, obscene cultural ideas, making college students lost their own life direction.

2) The school coping education model caused mental health problems

For a long time, most teachers' and parents' attention just focus on the student's examination and the school scores, and the school's educational mechanism has a lot of drawbacks (Chakrabarti, Kulhara, \& Verma, 1993). Professor Guo Faqi said, "Examination-oriented education is a high-load, high-pressure system," the school that only test scores; it means that students have high ability. However, the score does not represent everything. In recent years, we can see the news of "high scores and low energy" students, examination-oriented education confined teachers, parents, and students just look at the immediate score, do not look at the long-term comprehensive development of the dilemma. But college students are in the critical period of thinking development, they also have a variety of psychological needs. Even if some of the universities set up a psychological counseling center, but often no one works there, when the students have mental health problems when there is no way to tell, and ashamed to communicate with teachers, students, the long run, college students little confusion gradually become a psychological problem. Whether it is negative emotions, or emotional disorders, are caused by college students' mental health problems arising from the incentive. How to improve their teaching ideas and working methods in order to cope with the emergence of mental health problems of college students, colleges and universities need to carry out in-depth teaching and exploration.

3) The concept of family education caused mental health problems

As the earliest and most influential family environment for college students' 
mental health, they mainly include family atmosphere and family education (Coyne, Kessler, Tal, Turnbull, Wortman, \& Greden, 1987). Family atmosphere, including with parents, brothers and sisters get along the way, harmony and so on. If the relationship between family members is not harmonious (Hudson, 1992), high frequency of contradictions and disputes occur, the family atmosphere is suppressed; it is likely to cause college students mental health risks. Family education includes the way of daily education, the behavior of parents on their children, the way of economic domination.

4) Mental health problems caused by unbalanced self-development of college students

In the process of ideological and political education and mental health education for college students, the educators found that for some college students, even if the society actively advocated the correct way of life and philosophy (Cheug \& Hudson, 1982), the school conducts comprehensive quality education and the family to create a harmonious and positive atmosphere, they still have mental health problems, which cannot help but cause people's doubts (Goldberg, \& William, 1988). The reason is actually the development of college students in all aspects of the imbalance caused. Students in a special stage of growth, due to the high school in the examination mode of education, when they enter the university campus, the dazzling information into the spirit of the students in the world, the influx of complex information into the students self-consciousness has produced many unprecedented ideas, burst out a variety of ideals, but because of the lack of necessary practical social practice experience, so that their ideals and reality of the situation conflict, which lead to confusion, negative psychological problems. College students have their own mental health problems are: personality is not perfect, psychological fragility and so on.

\section{Methods to Deal with Psychological Health Education}

College students are people in society, their psychological state also matures, but the main environment for college students to study and live is the university campus, the understanding of reality is still not deep enough (Goldberg, 1992). For college students have all kinds of psychological problems, as ideological and political education workers, we should provide an effective solution (Goldberg, 1978). The role of the university is to cultivate all-round development of talent, not the labor force "copy". In the face of the rapid social life rhythm to bring college students in the heart of the urgent desire to distort the concept of success, should focus on the world outlook, outlook on life, the construction of values and the correct ideological and political concepts, health psychology (Okojie, 2011). Based on the purpose of cultivating college students, combining with the contemporary characteristics and positive factors, it is the most important problem to find effective countermeasures to solve the mental health problems of college students.

1) Vigorously carry forward the positive energy of the real social environment 
"The word" positive energy "is the original term of physics, referring to the positive energy, positive energy" Marxist theory of human nature is the sum of all social relations, people living in the real world, the nature of human beings is not congenital of the talent, but in the later days of social life and social practice, especially in the production practice in the formation. At the same time, human practice will have a dynamic role in the real world, making the reality of society showing a variety of state. The environment of Chinese society is harmonious and positive, and it is necessary to promote the positive energy of society and promote the development of college students' mental health (Williams, 2005).

2) Schools should strive to practice quality education

In today's world competition in the background of international competition, the quality of workers is an important guarantee for the strength of a country's national strength. The goal of cultivating ideological and political education is to adhere to the comprehensive development concept and promote the free and comprehensive development of human beings. And to enable students to obtain free and comprehensive development, its quality education is necessary. College students are a group of senior talent pool, a good quality education for them to become one of the most important tasks of colleges and universities. Quality education not only includes knowledge and skills learning, but also need personality and mental health education. Psychological quality is an important part of the formation of a complete quality education. Therefore, it is a key factor to solve the mental health problems of college students by carrying out comprehensive quality education for college students.

3) Family should pay attention to the education of college students

College students are in the rapid development stage, parents should follow the pace of follow up the psychological age of college students to guide and manage (Adesanya, 2002). At present, college students are basically 90, which requires parents to first understand their general laws of psychological development, according to the main existence of college students to analyze and guide the status quo. Combined with books, online media tries to find their own existence in the theory and method of error, timely update the concept, to correct ways and methods. This will not only help to reduce the psychological hidden dangers of college students and parents, but also can improve the overall quality of the community in the province. Parents should cultivate family members with a democratic, harmonious get along; pay attention to each member in the family should have equal rights, with family cohesion. In management, communication is an important part. However, the family is like a team, need to communicate and cooperation in order to promote common development. Therefore, parents should be in the family to cultivate members of the exchange and communication between the good habits.

4) College students should pay attention to balanced development

First of all, college students should always reflect on self-psychological behavior and external behavior, an objective analysis of their own advantages and 
disadvantages, to develop their own behavior goals (Whisman, Uebelacker, \& Weinstock, 2004). But also can develop a reflection plan, or with students to carry out recognition and criticism of the meeting, help students' correct self-awareness. Second, college students can refer to the university evaluation indicators or related network assessment questions on their own mental health status to do a preliminary understanding, you can regularly go to the university mental health advisory body, access to some relevant test information, self-scientific quantitative test, in order to more Good evaluation of self, the right to face their own advantages and disadvantages. Thirdly, the ability of self-regulation of college students is the ability to control themselves in the emotional and behavioral sense of their psychological problems in life and learning, and make their own psychological ability to achieve good state. In the regulation of the role of the swap, the transfer of the scene, according to the scientists discussed the appropriate cry can resolve their own pressure; active participation in outdoor activities can be transferred to the distress of bad emotions can also find friends or family talk, not only can enhance and Other people's feelings, but also excretion of their own bad mood.

\section{Conclusion and Suggestion}

In the face of the current problems of mental health of college students, this study from the perspective of ideological and political education, the psychological problems of college students and their causes of research, puts forward effective solutions for the future of college students to solve the problem of mental health. It is helpful to understand the law of college students' own development and improve the quality of human resources. In order to solve the problem of mental health in college students, we should pay attention to the social environment, school environment and family environment of college students in order to solve the problems of mental health in college students, and obtain the factors of college students' mental health. In the process of cultivating college students, the society, schools and families should pay attention to the impact of the development of new media on the mental health of college students, so as to carry out effective education and training.

Nowadays, the importance of society, school and family's attention to college students' mental health education gradually increases. In the course of future mental health education, ideological and political education workers will find more ways to solve the problem of mental health of college students. As the main force of Chinese socialist construction reserve talents, college students have a healthy psychological quality, the future of their own development and social comprehensive construction will play a very important role. In the process of the innovation and development of ideological and political education, we hope to improve the system of college students' mental health education step by step in the course of the progress of ideological and political education in our country, such as social economy, political culture and so on. 


\section{References}

Adesanya, S. A. (2002). Correlates of Marital Stability among Couples in South Western Nigeria. Unpublished PhD Thesis, Ado-Ekiti: University of Ado-Ekiti.

Arrindell, W. A., \& Emmelkamp, P. M. G. (1986). Marital Adjustment, Intimacy, and Needs in Female Agoraphobics and Their Partners: A Controlled Study. British Journal of Psychiatry, 149, 592-602. https://doi.org/10.1192/bjp.149.5.592

Bauserman, S. A. K., Arias, I., \& Craighead, W. E. (1995). Marital Attributions in Spouses of Depressed Patients. Journal of Psychopathology and Behavioral Assessment, 17, 231-249. https://doi.org/10.1007/BF02229300

Chakrabarti, S., Kulhara, P., \& Verma, S. K. (1993). The Pattern of Burden in Families of Neurotic Patients. Social Psychiatry and Psychiatric Epidemiology, 28, 172-177. https://doi.org/10.1007/BF00797319

Chambless, D. L., Fauerbach, J. A., Floyd, F. J., Wilson, K. A., Remen, A. L., \& Renneberg, B. (2002). Marital Interaction of Agoraphobic Women: A Controlled, Behavioral Observation Study. Journal of Abnormal Psychology, 111, 502-512.

https://doi.org/10.1037/0021-843X.111.3.502

Cheug, P. P., \& Hudson, W. W. (1982). Assessment of Marital Discord in Social Work Practice: A Revalidation of the Index of Marital Satisfaction. Journal of Social Service Research, 5, 101-118. https://doi.org/10.1300/J079v05n01_07

Coyne, J. C., Kessler, R. C., Tal, M., Turnbull, J., Wortman, C. B., \& Greden, J. F. (1987). Living with a Depressed Person. Journal of Consulting and Clinical Psychology, 55, 347-352. https://doi.org/10.1037/0022-006X.55.3.347

Fals-Stewart, W., Birchler, G. R., \& O’Farrell, T. J. (1999). Drug-Abusing Patients and Their Intimate Partners: Dyadic Adjustment, Relationship Stability, and Substance Use. Journal of Abnormal Psychology, 108, 11-23. https://doi.org/10.1037/0021-843X.108.1.11

Goldberg, D. P. (1978). Manual of the General Health Questionnaire (pp. 8-12). Windsor: NFER-NELSON Publishers.

Goldberg, D. P. (1992). The Detection of Psychiatric Illness by Questionnaire (pp. 1-3). Oxford: Oxford University Press.

Goldberg, D. P., \& William, P. A. (1988). User's Guide to the General Health Questionnaire (pp. 4-5). Windsor: NFER-NELSON Publishers.

Hudson, W. W. (1992). Index of Marital Satisfaction (pp. 34-35). Tempe: Walmyr Publishing Co.

Huseman, R., Hatfield, J., \& Miles, E. (1987). A New Perspective on Equity Theory: The Equity Sensitivity Construct. Academy of Management Review, 12, 232-234.

Judge, T. A., Locke, E. A., \& Durham, C. C. (1997). The Dispositional Causes of Job Satisfaction: A Core Evaluations Approach. Research in Organizational Behavior, 19, 151-188.

Mount, M., Ilies, R., \& Johnson, E. (2006). Relationship of Personality Traits and Counterproductive Work Behaviors: The Mediating Effects of Job Satisfaction. Personnel Psychology, 59, 591-622.

Okojie, C. E. E. (2011). Achieving Gender Equality and Women's Empowerment in Nigeria: Should Women Wait in Hope or Expectation (pp. 1-6)? Inaugural Lecture Series 120, Benin: University of Benin.

Rode, J. C. (2004). Job Satisfaction and Life Satisfaction Revisited: A Longitudinal Test of an Integrated Model. Human Relations, 57, 1205-1230. 
https://doi.org/10.1177/0018726704047143

Saari, L. M., \& Judge, T.A. (2004). Employee Attitudes and Job Satisfaction. Human Resource Management, 43, 395-407.

Vega, B. R., Bayon, C., Franco, B., Canas, F., Graell, M., \& Salvador, M. (1993). Parental Rearing and Intimate Relations in Women's Depression. Acta Psychiatrica Scandinavica, 88, 193-197. https://doi.org/10.1111/j.1600-0447.1993.tb03438.x

Walster, E., Berscheid, E., \& Walster, G. W. (1973). New Directions in Equity Research. Journal of Personality and Social Psychology, 25, 151-176. https://doi.org/10.1037/h0033967

Wegge, J., Schmidt, K., Parkes, C., \& van Dick, K. (2007). “Taking a Sickie”: Job Satisfaction and Job Involvement as Interactive Predictors of Absenteeism in a Public Organization. Journal of Occupational and Organizational Psychology, 80, 77-89.

Whisman, M. A., \& Uebelacker, L. A. (2003). Comorbidity of Relationship Distress and mental and Physical Health Problems. In: D. K. Snyder, \& M. A. Whisman (Eds.), Treating Difficult Couples: Helping Clients with Coexisting Mental and Relationship Disorders (pp. 3-26). New York: Guilford Press.

Whisman, M. A., Uebelacker, L. A., \& Weinstock, L. M. (2004). Psychopathology and Marital Satisfaction: The Importance of Evaluating Both Partners. Journal of Consulting and Clinical Psychology, 72, 830-838. https://doi.org/10.1037/0022-006X.72.5.830

Williams, M. (2005). A Simple-Gender Aware Framework for Research and Advocacy on Trade Agreements and Trade Policy. In Symposium on Gender and Trade Liberalization: Global-Local Processes and Gendered Impacts in Asia and Beyond.

Submit or recommend next manuscript to SCIRP and we will provide best service for you:

Accepting pre-submission inquiries through Email, Facebook, LinkedIn, Twitter, etc. A wide selection of journals (inclusive of 9 subjects, more than 200 journals) Providing 24-hour high-quality service User-friendly online submission system Fair and swift peer-review system Efficient typesetting and proofreading procedure Display of the result of downloads and visits, as well as the number of cited articles Maximum dissemination of your research work

Submit your manuscript at: http://papersubmission.scirp.org/

Or contact ce@scirp.org 